\title{
Erik Thorbecke*
}

December 2006

\begin{abstract}
The evolution of the development doctrine over the last six decades is analysed in some detail in this paper. The development doctrine is defined as the body of knowledge consisting of four interrelated components: (1) the prevailing development objectives; (2) the conceptual state of the art relating to development theories, models, techniques and applications; (3) the underlying data system; and (4) the resulting development strategy. The main contributions and changes in these four components are traced through, decade by decade, starting with the 1950s.
\end{abstract}

Keywords: development, doctrine, evolution

JEL classification: O10, O20, B20

Copyright (c) UNU-WIDER 2006

*Cornell University

This study is a revised version of the paper presented at the 17-18 June 2005 UNU-WIDER anniversary conference, 'WIDER Thinking Ahead: The Future of Development Economics', directed by George Mavrotas and Anthony Shorrocks.

UNU-WIDER gratefully acknowledges the financial contributions to the research programme by the governments of Denmark (Royal Ministry of Foreign Affairs), Finland (Ministry for Foreign Affairs), Norway (Royal Ministry of Foreign Affairs), Sweden (Swedish International Development Cooperation Agency_Sida) and the United Kingdom (Department for International Development). 
The World Institute for Development Economics Research (WIDER) was established by the United Nations University (UNU) as its first research and training centre and started work in Helsinki, Finland in 1985. The Institute undertakes applied research and policy analysis on structural changes affecting the developing and transitional economies, provides a forum for the advocacy of policies leading to robust, equitable and environmentally sustainable growth, and promotes capacity strengthening and training in the field of economic and social policy making. Work is carried out by staff researchers and visiting scholars in Helsinki and through networks of collaborating scholars and institutions around the world.

www.wider.unu.edu

publications@wider.unu.edu

UNU World Institute for Development Economics Research (UNU-WIDER)

Katajanokanlaituri 6 B, 00160 Helsinki, Finland

Camera-ready typescript prepared by Lorraine Telfer-Taivainen at UNU-WIDER

The views expressed in this publication are those of the author(s). Publication does not imply endorsement by the Institute or the United Nations University, nor by the programme/project sponsors, of any of the views expressed. 


\section{Introduction}

The economic and social development of the Third World, as such, was clearly not a policy objective of the colonial rulers before the Second World War.1 Such an objective would have been inconsistent with the underlying division of labour and trading patterns within and among colonial blocks. It was not until the end of the colonial system in the late 1940s and 1950s, and the subsequent creation of independent states, that the revolution of rising expectations could start. Thus, the end of Second World War marked the beginning of a new regime for the less developed countries involving the evolution from symbiotic to inward-looking growth and from a dependent to a somewhat more independent relation vis-à-vis the ex-colonial powers. It also marked the beginning of serious interest among scholars and policymakers in studying and understanding better the development process as a basis for designing appropriate development policies and strategies. In a broad sense a conceptual development doctrine had to be built which policymakers in the newly independent countries could use as a guideline to the formulation of economic policies.

The selection and adoption of a development strategy - that is, a set of more or less interrelated and consistent policies-depend upon three building blocks: (1) the prevailing development objectives which, in turn, are derived from the prevailing view and definition of the development process; (2) the conceptual state of the art regarding the existing body of development theories, hypotheses, models, techniques, and empirical applications; and (3) the underlying data system available to diagnose the existing situation, measure performance, and test hypotheses.

Figure 1 illustrates the interrelationships and interdependence which exist among (i) development theories and models, (ii) objectives, (iii) data systems and the measurement of performance, and (iv) development policies, institutions and strategies, respectively. These four different elements are identified in four corresponding boxes in Figure 1. At any point in time or for any given period these four sets of elements (or boxes) are interrelated. Thus, it can be seen from Figure 1 that the current state of the art, which is represented in the southwest box embracing developments theories, hypotheses and models, affects and is, in turn, affected by the prevailing development objectives-hence the two arrows in opposite directions linking these two boxes. Likewise, data systems emanate from the existing body of theories and models and are used to test prevailing development hypotheses and to derive new ones. Finally, the choice of development policies and strategies is jointly determined and influenced by

1 This paper is based on and updates an earlier paper by Thorbecke (2000). 
Figure 1: Development doctrine: key interrelationships

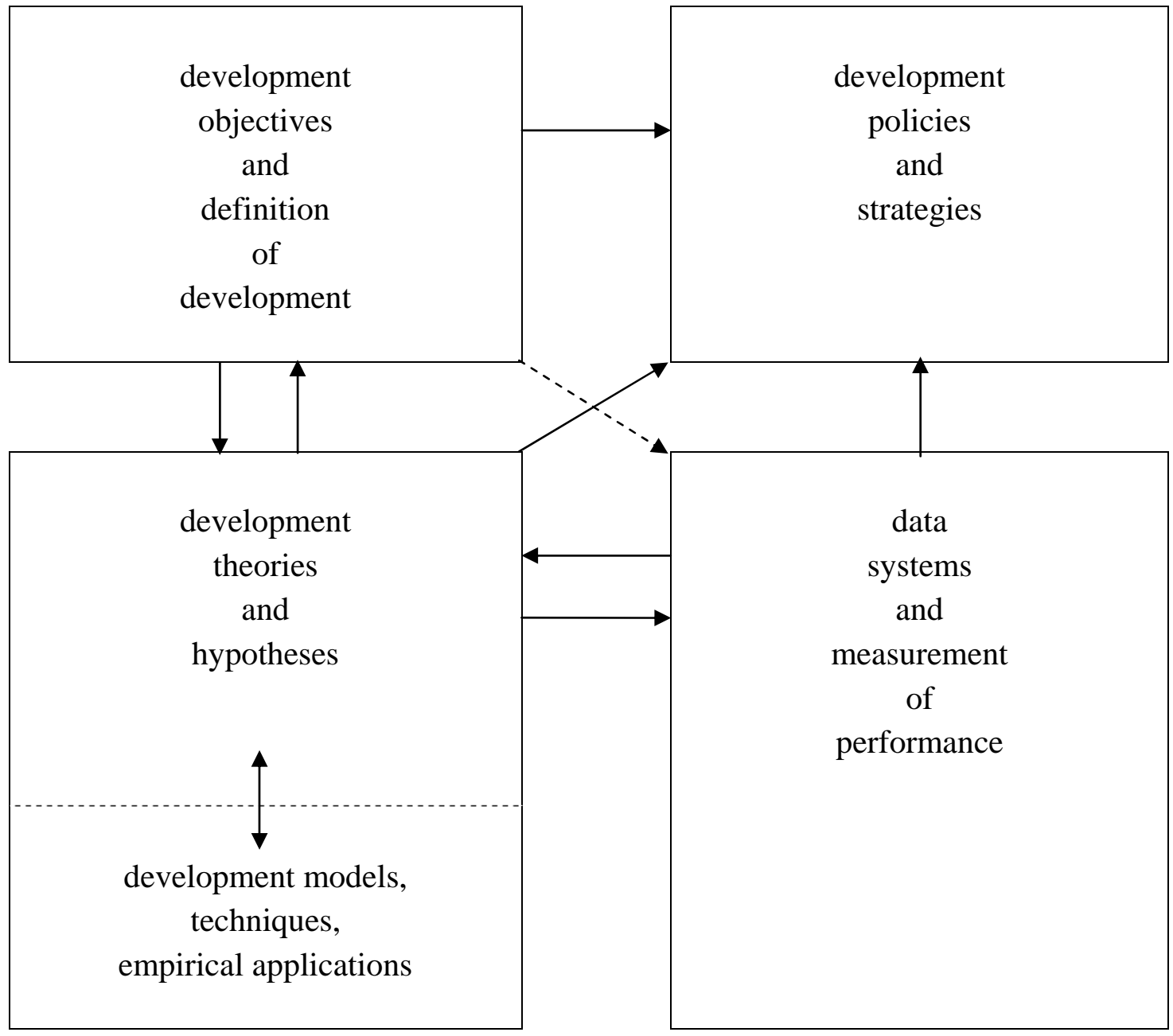

the other three elements_objectives, theories and data, as the three corresponding arrows indicate. ${ }^{2}$

The analytical framework presented above and outlined in Figure 1 is applied to describe the state of the art that prevailed in each of the last six decades to highlight in a systematic fashion the changing conception of the development process. The choice of the decade as a relevant time period is of course arbitrary and so is, to some extent, the

2 There are two additional reciprocal relationships denoted by arrows in Figure 1 . The first one is the interaction between development theories and hypotheses and development models. Models are typically based on theoretical hypotheses, which often are of a partial nature. By integrating various hypotheses into a consistent framework, which the model provides, some new insights may be derived which could lead to a modification of the initial hypotheses. The second bi-directional arrow is the one linking development objectives and data systems. Clearly, the choice of development goals both predetermines the kind of data systems that is required and is affected by it. Many concrete examples of these interrelationships are described and analysed next in the application of the conceptual framework in Figure 1 to the five decades spanning the period 1950-2005. 
determination of what should be inserted in the four boxes in Figure 1 for each of the six decades under consideration. 3

Figures 2-7 attempt to identify for each decade the major elements which properly belong in the four interrelated boxes. In a certain sense it can be argued that the interrelationships among objectives, theories and models, data systems and hypotheses and strategies constitute the prevailing development doctrine for a given time period. A brief sequential discussion of the prevailing doctrine in each of the last five decades provides a useful way of capturing the evolution that development theories and strategies have undergone. A final section sums up and concludes.

\section{The development doctrine during the 1950s}

Economic growth became the main policy objective in the newly independent less developed countries. It was widely believed that through economic growth and modernization per se, dualism, and associated income and social inequalities which reflected it, would be eliminated. Other economic and social objectives were thought to be complementary to, if not resulting from, GNP growth. Clearly, the adoption of GNP growth as both the objective and yardstick of development was directly related to the conceptual state of the art in the 1950s. The major theoretical contributions which guided the development community during that decade were conceived within a onesector, aggregate framework and emphasised the role of investment in modern activities. The development economists' tool kit in the 1950s contained such theories and concepts as the 'big push’ (Rosenstein-Rodan 1943), 'balanced growth’ (Nurkse 1953), 'take-off into sustained growth' (Rostow 1956) and 'critical minimum effort thesis’ (Leibenstein 1957) (see Figure 2).

What all of these concepts have in common, in addition to an aggregate framework, is equating growth with development and viewing growth in less developed countries as essentially a discontinuous process requiring a large and discrete injection of investment. The 'big push' theory emphasised the importance of economies of scale in overhead facilities and basic industries. The 'take off' principle was based on the simple Harrod-Domar identity that in order for the growth rate of income to be higher than that of the population (so that per capita income growth is positive) a minimum threshold of the investment to GNP ratio is required given the prevailing capital-output ratio. In turn, the 'critical minimum effect thesis' called for a large discrete addition to investment to trigger a cumulative process within which the induced income-growth forces dominate

3 In particular, certain conceptual and theoretical contributions may have been formulated before they became part of the conventional wisdom. An example of this is the seminal article of Lewis (1954), which triggered the economic dualism concept which became a major element of the development paradigm of the 1960s rather than of the 1950s. 
Figure 2: Development doctrine during the 1950s

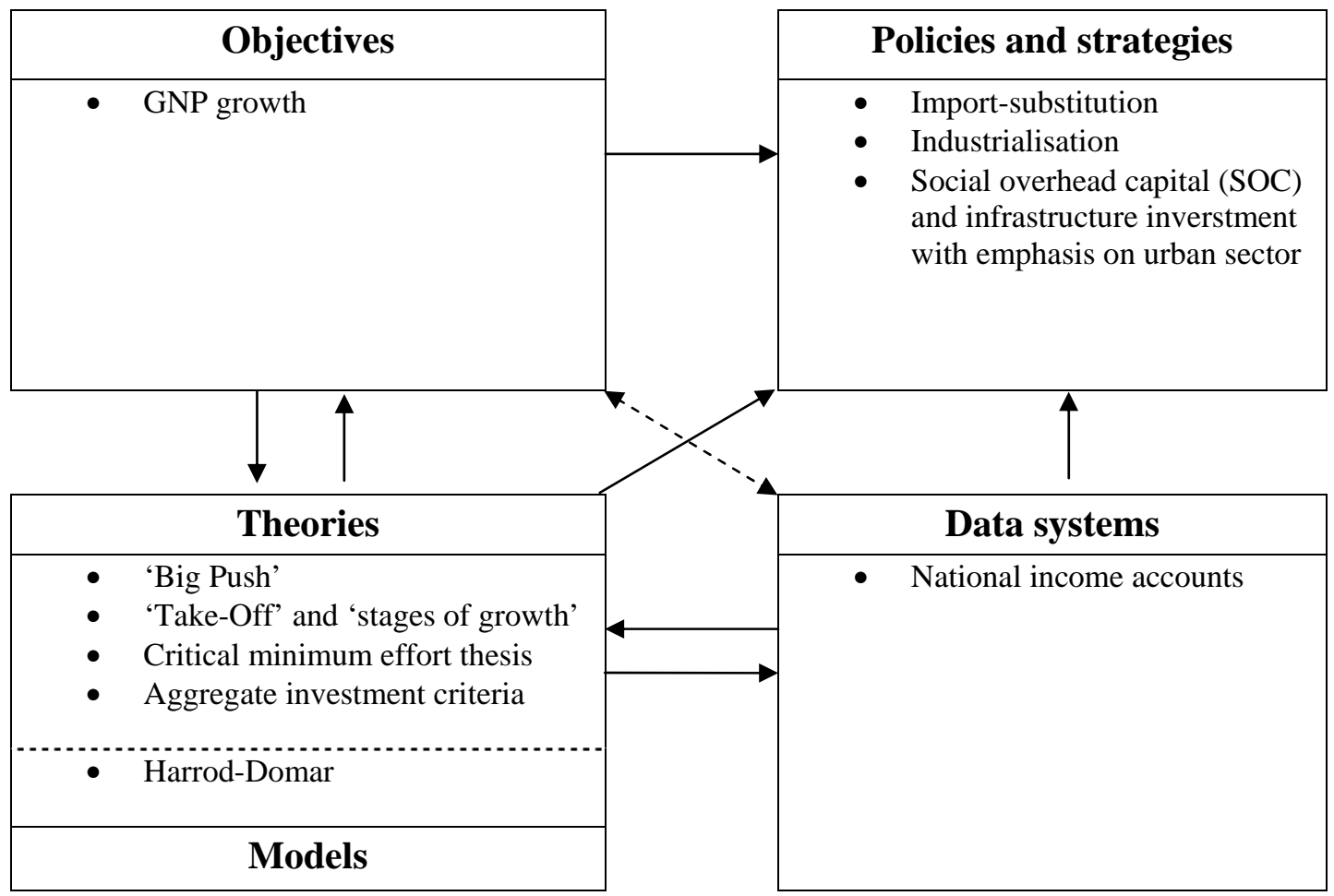

induced income-depressing forces. Finally, Nurkse's (1953) 'balanced growth' concept stressed the external economies inherent on the demand side in a mutually reinforcing and simultaneous expansion of a whole set of complementary production activities which combine together to increase the size of the market. It does appear, in retrospect, that the emphasis on large-scale investment in the 1950s was strongly influenced by the relatively successful development model and performance of the Soviet Union between 1928 and 1940.

The same emphasis on the crucial role of investment as a prime mover of growth is found in the literature on investment criteria in the 1950s. The key contributions were (i) the 'social marginal production' criterion (Kahn 1951; Chenery 1953), (ii) the 'marginal per capita investment quotient' criterion (Galenson and Leibenstein 1955) and (iii) the 'marginal growth contribution' criterion (Eckstein 1957).

It became fashionable to use as an analytical framework one-sector models of the Harrod-Domar type which, because of their completely aggregated and simple production functions, with only investment as an element, emphasised at least implicitly investment in infrastructure and industry. The one-sector, one-input nature of these models precluded any estimation of the sectoral production effects of alternative investment allocations and of different combinations of factors since it was implicitly assumed that factors could only be combined in fixed proportions with investment. In a one-sector world GNP is maximized by pushing the investment-ratio (share of investment in GNP) as high as is consistent with balance-of-payments' equilibrium. In the absence of either theoretical constructs or empirical information on the determinants 
of agricultural output, the tendency was to equate the modern sector with high productivity of investment and thus, direct the bulk of investment to the modern sector and to the formation of social overhead capital—usually benefiting the former.

The reliance on aggregate models was not only predetermined by the previously discussed conceptual state of the art but also by the available data system which, in the 1950s, consisted almost exclusively of national income accounts. Disaggregated information in the form of input-output tables appeared in the developing countries only in the 1960s.

The prevailing development strategy in the 1950s follows directly and logically from the previously discussed theoretical concepts. Industrialization was conceived as the engine of growth which would pull the rest of the economy along behind it. The industrial sector was assigned the dynamic role in contrast to the agricultural sector which was, typically, looked at as a passive sector to be 'squeezed' and discriminated against. More specifically, it was felt that industry, as a leading sector, would offer alternative employment opportunities to the agricultural population, would provide a growing demand for foodstuffs and raw materials, and would begin to supply industrial inputs to agriculture. The industrial sector was equated with high productivity of investment - in contrast with agriculture-and, therefore, the bulk of investment was directed to industrial activities and social overhead projects. 4 To a large extent the necessary capital resources to fuel industrial growth had to be extracted from traditional agriculture.

Under this 'industrialization-first' strategy the discrimination in favour of industry and against agriculture took a number of forms. First, in a large number of countries, the internal terms of trade were turned against agriculture through a variety of price policies which maintained food prices at an artificially low level in comparison with industrial prices. One purpose of these price policies - in addition to extracting resources from agriculture - was to provide cheap fuel to the urban workers and thereby tilt the income distribution in their favour. Other discriminatory measures used were a minimal allocation of public resources (for both capital and current expenditures) to agriculture and a lack of encouragement given to the promotion of rural institutions and rural offfarm activities. In some of the larger developing countries, such as India and Pakistan, the availability of food aid on very easy terms — mainly under US Public Law 480 — was an additional element which helped maintain low relative agricultural prices. 5

\footnotetext{
4 Here again the emphasis on industrialization was greatly influenced by the Soviet model.

5 Public Law (PL) 480 refers to the Agricultural Trade Development and Assistance Act passed in the United States in 1954, marking the inception of food aid programmes.
} 
A major means of fostering industrialization, at the outset of the development process, was through import substitution-particularly of consumer goods and consumer durables. With very few exceptions the whole gamut of import substitution policies, ranging from restrictive licensing systems, high protective tariffs and multiple exchange rates to various fiscal devices, sprang up and spread rapidly in developing countries. This inward-looking approach to industrial growth led to the fostering of a number of highly inefficient industries.

It should not be inferred that the emphasis on investing in the urban modern sector in import-substituting production activities and physical infrastructure was undesirable from all standpoints. This process did help start industrial development and contributed to the growth of the modern sector. It may even, in some cases, have provided temporary relief to the balance-of-payments constraint. However, by discriminating against exports - actual and potential-the long-run effects of import substitution on the balance-of-payments may well turn out to have been negative.

\section{The development doctrine during the 1960s}

Figure 3 captures the major elements of the development doctrine prevailing in the 1960s. On the conceptual front, the 1960s was dominated by an analytical framework based on economic dualism. Whereas the development doctrine of the 1950s implicitly recognised the existence of the backward part of the economy complementing the modern sector, it lacked the dualistic framework to explain the reciprocal roles of the two sectors in the development process. The naive two-sector models à la Lewis (1954) continued to assign to subsistence agriculture an essentially passive role as a potential source of 'unlimited labour' and 'agricultural surplus' for the modern sector. It assumed that farmers could be released from subsistence agriculture in large numbers without a consequent reduction in agricultural output while simultaneously carrying their own bundles of food (i.e. capital) on their backs or at least having access to it.

As the dual-economy models became more sophisticated, the interdependence between the functions that the modern industrial and backward agricultural sectors must perform during the growth process was increasingly recognised (Fei and Ranis 1964). The backward sector had to release resources for the industrial sector, which in turn had to be capable of absorbing them. However, neither the release of resources nor the absorption of resources, by and of themselves, were sufficient for economic development to take place. Recognition of this active interdependence was a large step forward from the naive industrialization-first prescription because the above conceptual framework no longer identified either sector as leading or lagging. 
Figure 3: Development doctrine during the 1960s

\begin{tabular}{|c|c|}
\hline Objectives & Policies and strategies \\
\hline $\begin{array}{ll} & \text { GNP growth } \\
\text { - } & \text { Balance-of-payments equilibrium } \\
\text { - } & \text { Employment }\end{array}$ & $\begin{array}{ll}\text { - } & \text { Fine-tuning and appropriate } \\
& \text { prices } \\
\text { - } & \text { 'Balanced growth' between } \\
& \text { agriculture and industry } \\
\text { - } & \text { Export promotion } \\
\text { - } & \text { Foreign aid } \\
\text { - } & \text { Regional integration } \\
\text { - } & \text { Fiscal reforms } \\
\text { - } & \text { Sectoral plans }\end{array}$ \\
\hline Theories & Data systems \\
\hline $\begin{array}{ll} & \text { Economic dualism } \\
\text { - } & \text { Balanced v. unbalanced growth } \\
\text { - } & \text { Inter-sectoral linkages } \\
\text { - } & \text { Effective protection } \\
\text { - } & \text { Shaman capital } \\
\text { - } & \text { Choice of technique } \\
\text { - } & \text { Patterns of growth } \\
\text { Role of agriculture }\end{array}$ & $\begin{array}{ll}- & \text { National income accounts } \\
- & \text { Input-output } \\
- & \text { Employment censuses } \\
- & \text { Social National Accounts } \\
& \text { (SNA) }\end{array}$ \\
\hline $\begin{array}{ll}- & \text { Two-gap } \\
\text { - } & \text { Semi input-output } \\
\text { - } & \text { Simple general equilibrium } \\
\text { - } & \text { Linear programming }\end{array}$ & \\
\hline Models and techniques & \\
\hline
\end{tabular}

A gradual shift of emphasis took place regarding the role of agriculture in development. Rather than considering subsistence agriculture as a passive sector whose resources had to be squeezed in order to fuel the growth of industry and to some extent modern agriculture, it started to become apparent in the second half of the 1960s that agriculture could best perform its role as a supplier of resources by being an active and co-equal partner with modern industry. This meant in concrete terms that a gross flow of resources from industry to agriculture may be crucial at an early stage of development to generate an increase in agricultural output and productivity which would facilitate the extraction of a new transfer out of agriculture and into the modern sector. The trouble with the alternative approach which appears to have characterized the 1950s of squeezing agriculture too hard or too early in the development process was described in the following graphic terms: 'The backwards agricultural goose would be starved before it could lay the golden egg' (Thorbecke 1969: 3). 
The 'balanced' versus 'unbalanced' growth issue was much debated during the 1960s. In essence, the balanced growth thesis (Nurkse 1953) emphasised the need for the sectoral growth of output to be consistent with the differential growth of demand for different goods as income rises. Unbalanced growth, on the other hand, identified the lack of decision making ability in the private and public sectors as the main bottleneck to development (Hirshman 1958). The prescription for breaking through this bottleneck was to create a sequence of temporary excess capacity of social overhead facilities which, by creating a vacuum and an attractive physical environment, would encourage the build-up of directly productive activities. Alternatively, the process could start by a build-up of directly productive activities ahead of demand, which, in turn, would generate a need for complementary social overhead projects.

The similarities between the balanced and unbalanced growth theses are more important than their apparently different prescriptions. Both approaches emphasised the role of inter-sectoral linkages in the development process. In a certain sense they extended the dual-economy framework to a multi-sectoral one without, however, capturing the essential differences in technology and form of organization between modern and traditional activities. This was at least partially due to the type of sectoral disaggregation available in the existing input-output tables of developing countries during the 1960s. Except for the various branches of industry, the level of sectoral aggregation tended to be very high, with agricultural and service activities seldom broken down in more than two or three sectors. Consequently, any attempt at distinguishing traditional, labourintensive activities from modern, capital-intensive activities in either agriculture or in service, could not be performed given the classification criteria underlying input-output tables. This example illustrates the interdependence that exists between the prevailing data systems and the conceptual framework in the actual formulation of development plans and strategies. This is an issue which is returned to subsequently.

Another contribution of the late 1960s which was imbedded in inter-sectoral (inputoutput) analysis is the theory of effective protection, which clarified and permitted the measurements of the static efficiency cost of import substitution when both inputs and outputs are valued at world prices. Still another important set of contributions that appeared in the 1960s relates to the inter-sectoral structure and pattern of economic growth. Two different approaches provided important insights into the changing inter-sectoral structure of production and demand throughout the process of economic development. The first approach, based largely on the work of Kuznets (1966), relied on a careful and painstaking historical analysis of a large number of countries. The second approach was pioneered by Chenery and based on international cross-sectional analysis which was subjected to regression analysis to derive what appeared to be structural phenomena in the process of growth (Chenery 1960; Chenery and Taylor 1968). 
The models that were designed in the 1960s can be divided into three types: (i) two-gap models, (ii) semi-input-output models and (iii) simple general equilibrium models. The first type tried to incorporate into a macroeconomic model the role of foreign aid (Chenery and Strout 1966). The underlying logic of these models is that two independent constraints may limit economic growth. The first constraint on skills and savings, if it were the binding one, is described as the investment-limited growth. Alternatively, when the balance-of-payments constraint is effective, trade limited growth would follow. This is a disequilibrium-type model which assumes that developing countries are characterized by limited structural flexibility — with either the investment-savings gap or the balance-of-payments gap binding at any one point in time.

The other types of models (ii and iii above) rely on an inter-sectoral input-output framework. The semi-input-output method initiated by Jan Tinbergen distinguishes between international sectors which produce tradable foods and national sectors which produce non-tradable goods (Kuyvenhoven 1978). Hence, the required capacity expansion throughout the growth process can be computed for, at least, the non-tradable sectors. The general equilibrium models which appeared in the 1960s were either of a consistency or linear programming type. The main purpose of these models was to throw more light on the inter-sectoral linkages and the effects of alternative sectoral investment allocations on economic growth (Fox et al. 1972; Manne 1974).

The conception of economic development in the 1960s was still largely centred on GNP growth as the key objective. In particular, the relationship between growth and the balance-of-payments was made clearer. Toward the end of this decade the increasing seriousness of the under- and unemployment problem in the developing world led to a consideration of employment as an objective in its own right next to GNP growth. The most noteworthy change in the conception of development was the concern for understanding better the inter-sectoral structure and physiology of the development process - as the preceding review of the conceptual state of the arts revealed.

The development policies and strategies that prevailed in the 1960s flowed directly from the conceptual contributions, development objectives and the data system. These policies fall into a few categories, which are reviewed briefly below. The first set embraces the neoclassical prescription and can be expressed under the heading of 'fine tuning' and 'appropriate prices'. In a nutshell the 'fine tuning' instruments embrace the use of an appropriate price system (including commodity, tax and subsidy rates), the removal of market imperfections, and appropriate exchange rate and commercial policies. It was expected that these measures would lead to a more appropriate output mix between production activities and input mix, or choice of technique, and thereby generate increased employment. 
A second set of policies can be classified as essentially structural, emphasising the importance of inter-sectoral linkages. They include the allocation of investment and current public expenditures among sectors, so as to achieve a process of inter-sectoral balanced (or, in some instances, unbalanced) growth. More specifically, by the late 1960s agriculture was assigned a much more active role in the development process. The provision of a greater level of public resources to that sector-combined with less discriminatory price policies-were expected to result in a growth of output and productivity which would facilitate a net transfer back to the rest of the economy. The success of South Korea and Taiwan in nurturing their agricultural sector and using the agricultural surplus to achieve a successful industrial take-off was starting to resonate.

\section{The development doctrine in the 1970s}

Figure 4 summarizes the major development objectives, theories, data sources and policies prevailing in the 1970s. By the 1970s the failure of a GNP-oriented development strategy to cope successfully with increasingly serious development problems in much of the Third World led to a thorough re-examination of the process of economic and social development. The major development problems that became acute and could no longer be ignored during this decade can be summarized as:

(i) the increasing level and awareness of under- and unemployment in a large number of developing countries;

(ii) the tendency for income distribution within countries to have become more unequal or, at least, to have remained as unequal as in the immediate postSecond World War period;

(iii) the maintenance of a very large, and perhaps rising, number of individuals in a state of poverty; for instance, below some normative minimum income level or standard of living;

(iv) the continuing and accelerating rural-urban migration and consequent urban congestion; and finally

(v) the worsening external position of much of the developing world reflected by increasing balance-of-payments pressures and rapidly mounting foreign indebtedness and debt servicing burdens. Largely as a consequence of these closely interrelated problems a more equal income distribution, particularly in terms of a reduction in absolute poverty, was given a much greater weight in the preference function of most developing countries compared to the objective of aggregate growth per se. Furthermore, this reduction in absolute poverty was to be achieved mainly through increased productive employment (or reduced underemployment) in the traditional sectors. 
Figure 4: Development doctrine during the 1970s

\begin{tabular}{|c|c|}
\hline Objectives & Policies and strategies \\
\hline $\begin{array}{ll}- & \text { GNP growth } \\
- & \text { Employment } \\
- & \text { Income distribution } \\
\text { - } & \text { Poverty alleviation } \\
& \text { (e.g. 'basic needs') } \\
\text { - } & \text { External equilibrium }\end{array}$ & $\begin{array}{ll}\text { - } & \text { Integrated rural development } \\
\text { - } & \text { Comprehensive employment } \\
\text { - strategies } \\
\text { - 'Redistribution with growth' } \\
\text { - } \quad \text { 'Basic needs' } \\
\text { - Reformist } \\
\text { - } \quad \text { (asset redistribution) } \\
\text { Radical-collectivist }\end{array}$ \\
\hline Theories & Data systems \\
\hline $\begin{array}{ll}\text { - } & \text { Package approach in traditional } \\
\text { - } & \text { rural areas } \\
\text { - } & \text { Urban-rural migration } \\
\text { - } & \text { Appropriate technology } \\
\text { - } & \text { belationship and trade off } \\
& \text { income output, employment, } \\
\text { - } & \text { Socio-economic investment } \\
\text { criteria } & \text { Underdevelopment theory } \\
\text { - } & \text { Dependency theory }\end{array}$ & $\begin{array}{ll}\text { - } & \text { National income accounts } \\
\text { - } & \text { Input-output } \\
& \text { (inter- and intra-sectoral) } \\
\text { - } & \text { Employment censuses } \\
\text { - } & \text { Household surveys } \\
\text { - } & \text { Integrated rural surveys } \\
\text { - } & \text { Informal sector surveys } \\
& \text { Demographic data }\end{array}$ \\
\hline $\begin{array}{ll}- & \text { Multiple objectives } \\
\text { - } & \text { Computable General Equilibrium } \\
\text { (CGE) } \\
\text { - } & \text { Sectoral models (e.g. agriculture) }\end{array}$ & \\
\hline Models and techniques & \\
\hline
\end{tabular}

By the mid 1970s, GNP as a dominant all-encompassing objective had been widely, but by no means universally, dethroned. The presumption that aggregate growth is synonymous with economic and social development or, alternatively, that it will ensure the attainment of all other development objectives, came under critical scrutiny and was rejected in many circles. The launching of the World Employment Programme by the ILO in 1969 signalled that the primary objective should be to raise the standard of living of the poor through increased employment opportunities. The generation of new or greater productive opportunities was considered a means toward the improvement of the welfare of the poor.

The changing meaning of development as a process that should have as simultaneous objectives growth and poverty alleviation, both influenced and was influenced by a number of conceptual and empirical contributions. The first set of contributions comes under the rubric of integrated rural and agricultural development. A whole series of 
empirical studies at the micro- and macro-levels combined to provide an explanation of the physiology and dynamics of the transformation process of traditional agriculture. This body of knowledge provided a rationale for a unimodal strategy in the rural areas, which is discussed subsequently under the strategy box.

A second type of conceptual breakthroughs which appeared in the 1970s were those of the informal sector and the role of employment in furthering the development process. Even though the informal sector concept had been around a long time and taken a variety of forms such as Gandhi's emphasis on traditional cottage industries, it became revitalized in a more general and formal sense in the Kenya Report of International Labour Organization (ILO 1973). A number of case studies undertaken by ILO focussing specifically on the role of the informal sector concluded that it was relatively efficient, dynamic, and often strongly discriminated against as a result of market imperfections or inappropriate national or municipal regulations. These studies suggested that the informal activities represent an important potential source of output and employment growth. ILO's World Employment Programme and the World Bank generated much useful empirical research focused on such issues as the relationship between population growth and employment; appropriate labour-intensive technologies; the educational system-labour market-employment-income distribution nexus; the informal sector; the determinants of rural-urban migration and the role of traditional agriculture in the development process.

A third contribution which surfaced in the 1970s includes the interdependence between economic and demographic variables and the determinants of the rural-urban migration. A number of empirical studies, mainly at the micro level, attempted to throw some light on the relationship between such sets of variables as (i) education, nutrition and health and (ii) fertility, infant mortality and, ultimately, the birth rate. The hypotheses that were generated by these studies highlighted the complex nature of the causal relationship between population growth and economic development.

With regard to the determinants of migration, the initial Harris-Todaro (1970) formulation triggered a series of empirical studies and simple models of the migration process. In general, migration was explained as a function of urban-rural wage differentials weighted by the probability of finding urban employment. A somewhat parallel set of contributions at the micro-level consists of the attempt at incorporating socioeconomic objectives - such as employment and income distribution-among investment (benefit-cost) criteria and in the appraisal and selection of projects (Little and Mirrlees 1974).

A review of contributions to the state of the art in development economics would not be complete without at least a reference to the neo-Marxist literature on underdevelopment and dependency theories. The essence of these theories is that underdevelopment is intrinsic in a world trading and power system in which the developing countries make up the backward, raw material producing periphery, and the developed countries the 
modern industrialized centres (Hunt 1989). A neo-colonial system of exploitation by indigenous classes associated with foreign capital (for example, multinational corporations) is considered to have replaced the previous colonial system. After this review of major contributions to development theory, only a few words need be said about the nature of models which appeared in the 1970s. A major characteristic of these models was to explain, at the sectoral- and multi-sectoral levels, the simultaneous determination of output, employment and income distribution. Most of these models were partial in the sense that they did not capture the complete interdependence among these variables.

The coverage and quality of the data available improved substantially in the 1970s as compared to the previous decades. By the mid 1970s, survey-type information on variables such as employment, income, consumption and saving patterns were becoming available. A variety of surveys covering such diverse groups as urban, informal and rural households started to provide valuable information on the consumption and savings behaviour of different socioeconomic groups. In a number of developing countries it became possible, for the first time, to estimate approximately the income distribution by major socioeconomic groups.

After having reviewed the changing development objectives, conceptual contributions and data sources which marked the 1970s, the next logical step is to describe and analyse briefly the new development strategies that emerged. From a belief that growth was a necessary and sufficient condition for the achievement of economic and social development, it became increasingly recognised that even though necessary, growth might not be sufficient. The first step in the broadening process of moving from a single to multiple development objectives was a concern with, and incorporation of, employment in development plans and in the allocation of foreign aid to projects and technical assistance.

One possible attraction of using employment as a target was that it appeared, on the surface, to be relatively easily measurable, in somewhat the same sense as the growth rate of GNP had provided previously a simple scalar measure of development. The real and fundamental issue was an improvement in the standards of living of all groups in society and, in particular, that of the poorest and most destitute groups.

Two partially overlapping variants of a distributionally oriented strategy surfaced during this decade. These were 'redistribution with growth' and 'basic needs'. The first one was essentially incremental in nature, relying on the existing distribution of assets and factors and requiring increasing investment transfers in projects (mostly public but perhaps even private) benefiting the poor (Chenery et al. 1974). The first step in this strategy was the shift in the preference (welfare) function away from aggregate growth per se toward poverty reduction. This strategy, which was favoured by the World Bank, focussed on the redistribution of at least the increments of capital formation in contrast 
with the initial stock of assets. Since the bulk of the poor are located in the rural sector and the informal urban sector, this strategy had to be directed toward increasing the productivity of the small farmers and landless workers and making small-scale producers (mainly self-employed) in the informal urban sector more efficient.

The second alternative strategy inaugurated during the 1970s was the basic needs strategy, which was particularly advocated by the ILO.6 It entailed structural changes and some redistribution of the initial ownership of assets - particularly land reform-in addition to a set of policy instruments, such as public investment. Basic needs, as objectives defined by ILO, included two elements: (i) certain minimal requirements of a family for private consumption, such as adequate food, shelter and clothing and (ii) essential services provided by and for the community at large, such as safe drinking water, sanitation, health and educational facilities.

A complementary policy within the agricultural sector was that of integrated rural development. In a nutshell, the new approach centred on lending and technical activities benefiting directly the traditional sector. This strategy conformed to a broader so-called unimodal agricultural development strategy (Johnston and Kilby 1975). The latter relied on the widespread application of labour-intensive technology to the whole of agriculture. In this sense, it was based on the progressive modernization of agriculture 'from the bottom up'. This strategy can be contrasted with a bimodal strategy, which encourages the growth of the modern, commercial, large-scale, relatively capitalintensive sub-sector of agriculture while ignoring for all practical purposes the traditional subsistence sub-sector. Under the unimodal approach, agricultural development was spread relatively evenly over the mass of the people through a combination of appropriate agricultural research and technology, land redistribution, the provision of rural infrastructure, the growth of rural institutions and other measures. This approach was successful in accelerating the output of cereals and invigorating small-scale farms as it was linked to the dissemination of the green revolution technology.

A third type of development strategy follows from the neo-Marxist underdevelopment and dependency theories, which have been previously touched upon. This approach was radical, if not revolutionary, in nature. It called for a massive redistribution of assets to the state and the elimination of most forms of private property. It appeared to favour a collectivistic model-somewhat along the lines of the Chinese regime in power at that time-based on self-reliance and the adoption of indigenous technology and forms of organization.

6 Far from originating with ILO, the concept of basic needs and planning for poverty alleviation had already been expressed and formulated very clearly by the Indian planner Pitambar Pant as early as 1962 (see Pant 1974). 


\section{The development doctrine in the 1980s}

A combination of events including an extremely heavy foreign debt burden-reflecting the cumulative effects of decades of borrowing and manifested by large and increasing balance-of-payments and budget deficits in most of the developing world-combined with higher interest rates and a recession in creditor countries, radically changed the development and aid environment at the beginning of the 1980s. The Mexican financial crisis of 1982 soon spread to other parts of the Third World. The magnitude of the debt crisis was such that, at least for a while, it brought into question the survival of the international financial system.

Suddenly, the achievement of external (balance-of-payments) equilibrium and internal (budget) equilibrium became the overarching objectives and necessary conditions to the restoration of economic growth and poverty alleviation. The debt crisis converted the 1980s into the 'lost development decade'. Before the development and poverty alleviation path could be resumed, the Third World had to put its house in order and implement painful stabilization and structural adjustment policies.

Notwithstanding the fact that the development process was temporarily blocked and most of the attention of the development community was focussed on adjustment issues, some important contributions to development theory were made during this decade (see Figure 5).

The first one greatly enriched our understanding of the role of human capital as a prime mover of development. The so-called endogenous growth school (Lucas 1988; Romer 1990) identifies low human capital endowment as the primary obstacle to the achievement of the potential scale economies that might come about through industrialization. In a societal production function, raw (unskilled) labour and capital were magnified by a term representing human capital and knowledge, leading to increasing returns. This new conception of human capital helped convert technical progress from an essentially exogenously determined factor to a partially endogenously determined factor. Progress was postulated to stem from two sources: (i) deliberate innovations, fostered by the allocation of resources (including human capital) to research and development (R\&D) activities, and (ii) diffusion, through positive externalities and spillovers from one firm or industry to know-how in other firms or industries (Ray 1998). If investment in human capital and know-how by individuals and firms is indeed subject to increasing returns and externalities, it means that the latter do not receive the full benefits of their investment resulting, consequently, in underinvestment in human capital (the marginal social productivity of investment in human capital being larger than that of the marginal private productivity). The market is likely to under-produce human capital and this provides a rationale for the role of the government in education and training. 
Figure 5: Development doctrine during the 1980s

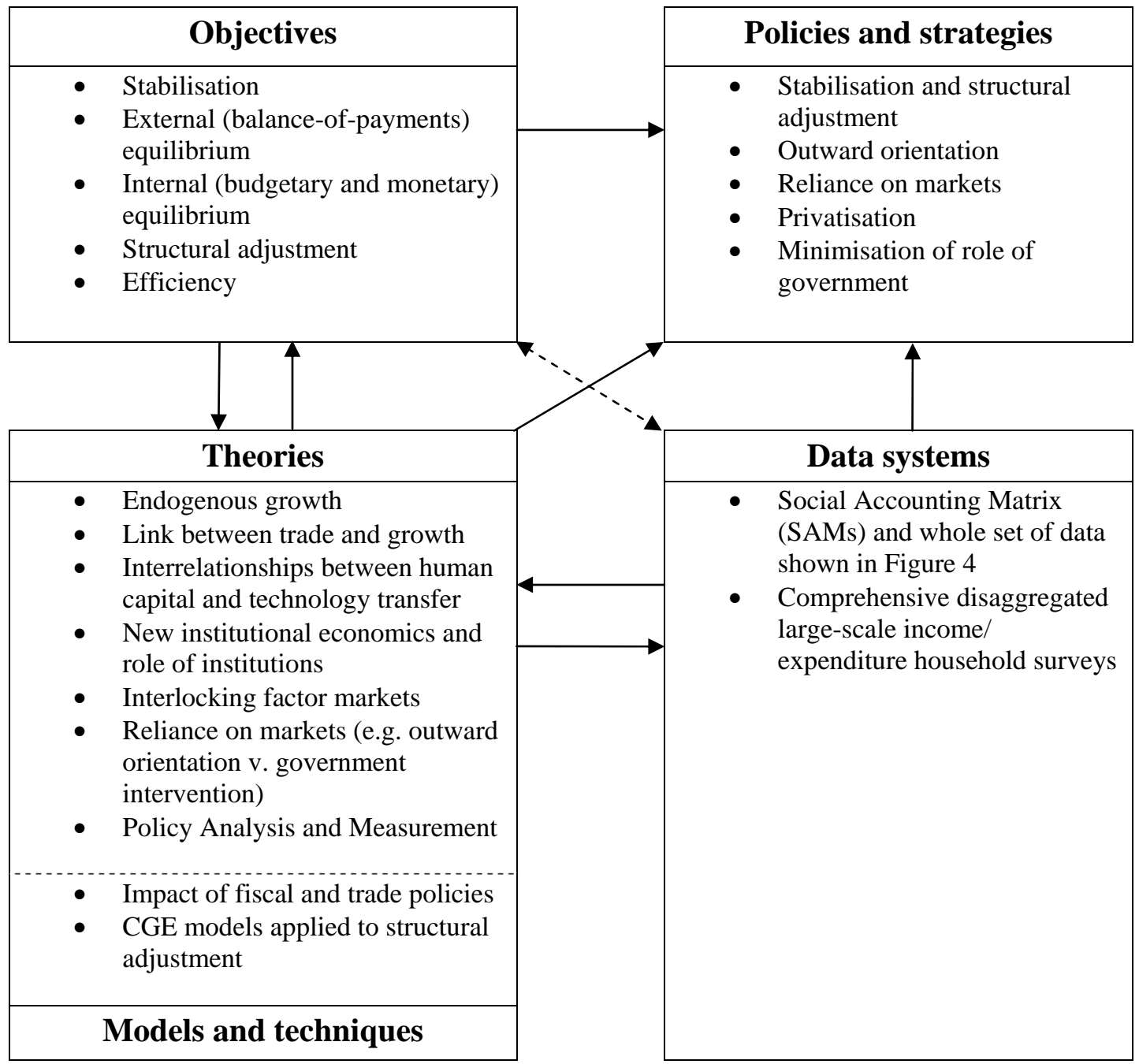

A second contribution based on a large number of quantitative and qualitative empirical studies-relying on international cross-sectional and country-specific analyses of performance over time-was the robust case made for the link between trade and growth. Outward-orientation was significantly and strongly correlated with growth. Countries that liberalized and encouraged trade grew faster than those that followed a more inward-looking strategy. The presumed mechanism linking export orientation to growth is based on the transfer of state of the art technology normally required to compete successfully in the world market for manufactures. In turn, the adoption of frontier technology by firms adds to the human capital of those workers and engineers through a process of 'learning-by-doing' and 'learning-by-looking' before spilling over to other firms in the same industry and ultimately across industries. In this sense, export orientation is a means of endogenizing and accelerating technological progress and growth. Furthermore, to the extent that outward orientation in developing countries normally entails a comparative advantage in labour-intensive manufactures, there is much evidence, based on the East and Southeast Asian experience, that the growth path that was followed was also equitable-resulting in substantial poverty alleviation (for a recent survey of the evidence linking trade to growth see Winters 2004). 
A third set of contributions that surfaced in the 1980s can be broadly catalogued under the heading of the 'new institutional economics' and collective action (North 1990; Williamson 1991; Nabli and Nugent 1989). As de Janvry et al. (1993: 565) noted, 'The main advance was to focus on strategic behaviour by individuals and organized groups in the context of incomplete markets. The theories of imperfect and asymmetrical information and, more broadly, transaction costs gave logic to the role of institutions as instruments to reduce transactions costs.' The neo-institutional framework, in addition to reminding the development community that appropriate institutions and rules of the game are essential to provide pro-development and anti-corruption incentives, also suggested broad guidelines in building institutions that reduced the scope for opportunistic behaviour.

Another contribution of this approach was to provide a clear rationale for the existence of efficient non-market exchange configurations, particularly in the rural areas. Prototypical examples of such institutions include intra-farm household transactions; twoparty contracts (sharecropping and interlinked transactions, for example), farmers' co-operatives and group organizations, mutual insurance networks and informal credit institutions (Thorbecke 1993). Those exchange non-market configurations-called agrarian institutions by Bardhan (1989) — owe their existence to lower transaction costs than those that would prevail in an alternative market configuration providing an equivalent good, factor or service. In most instances market imperfections or, at the limit, market failure (in which case there is no alternative market configuration and transaction costs become infinite) are at the origin of non-market configurations.

The 1980s witnessed some seminal contributions to a better understanding of the concept of poverty and its measurement. A comprehensive and operationally useful approach to poverty analysis was developed by Sen (1985) in his 'capabilities and functioning' theoretical framework. According to this framework what ultimately matters is the freedom of a person to choose her functionings. In order to function, an individual requires a minimum level of wellbeing brought about by a set of attributes. In turn, the Foster-Greer-Thorbecke (1984) class of decomposable poverty measures allowed poverty to be measured while satisfying most important welfare axioms.

A final contribution worth noting - which can be subsumed under the 'new institutional economies' heading-is that of interlinked transactions (Bardhan 1989). An interlinked contract is one in which two or more interdependent exchanges are simultaneously agreed upon (for instance, when a landlord enters into a fixed-rent agreement with a tenant and also agrees to provide credit at a given interest rate). In a more general sense, this type of contract leads to interlocking factor markets for labour, credit and land. In retrospect it is somewhat ironical that during a decade dominated by a faith in the workings of markets_-as is discussed subsequently_important theoretical contributions were made that highlighted market imperfections and failures. 
Some important contributions to general equilibrium modelling appeared during the 1980s (Dervis et al. 1982). These models—calibrated on a base year Social Accounting Matrix (SAM) reflecting the initial (base year) socioeconomic structure of the economy-proved particularly useful in tracing through the impact of a variety of exogenous shocks and policies (such as a devaluation, trade liberalization and fiscal reforms) on the income distribution by socioeconomic household groups. Computable General Equilibrium (CGE) models became an important tool to simulate the disaggregated impact of structural adjustment policies on growth and equity. In fact, these models provided the only means to compare the impact of adjustment scenarios to the counterfactual of no- or limited-adjustment scenarios. Since most applied CGEs were built in the 1990s, they are discussed in the next section.

The 1980s witnessed a proliferation of statistical information on a variety of dimensions of development and the welfare of households. Besides more elaborate and disaggregated employment, manufacturing, agricultural and demographic surveys and censuses, large-scale household income and expenditure surveys produced by statistical offices of most developing countries - and often designed and funded by the World Bank (for example, the Living Standard Measurement Surveys)—became available to analysts and policymakers. Perhaps for the first time, reasonably reliable and robust observations could be derived relating to the magnitude of poverty, the characteristics of the poor and the inter-household income distribution. In turn, the various data sources could be combined to build SAMs of a large number of countries.

The development strategy of the 1970s - centred on redistribution with growth and fulfilment of basic needs-was replaced by an adjustment strategy. The magnitude of the debt crisis and the massive internal and external disequilibrium, faced by most countries in Africa and Latin America and some in Asia, meant that adjustment became a necessary (although not sufficient) condition to a resumption of development. The main policy objective of Third World governments became macroeconomic stability, consisting of a set of policies to reduce their balance-of-payments deficits (for example, devaluation) and their budget deficits (through retrenchment). Whereas stabilization per se was meant to eliminate or reduce the imbalance between aggregate demand and aggregate supply, both externally and internally, structural adjustment was required to reduce distortions in relative prices and other structural rigidities that tend to keep supply below its potential. A typical adjustment package consisted of measures such as a devaluation, removal of artificial price distortions, trade liberalization, and institutional changes at the sector level.

Complementary elements of the prevailing adjustment strategy of the 1980s included outward orientation, reliance on markets and a minimization of the role of the government. The outward orientation was meant to encourage exports and industrialization in labour-intensive consumer goods. In turn, to achieve competitiveness in exports, vintage technology would have to be imported, which 
would trigger the endogenous growth processes described previously-investment in the human capital and knowledge of workers and engineers employing those technologies and subsequent spillover effects.

Under the influence of ideological changes in the Western World (for example, the Reagan and Thatcher administrations) developing countries were strongly encouraged, if not forced, to rely on the operation of market forces and in the process to minimize government activities in most spheres, not just productive activities. Inherent contradictions and conflicts arose among the elements of the broad adjustment strategy of the 1980s. The successful implementation of adjustment policies called for a strong government. Likewise, the rationale for a larger role of government in the education sphere to generate the social spillover effects and counteract the under-investment in education by private agents, which do not capture the positive externalities of their investment, ran counter to the objective of a minimalist state. Another conflict was caused by the stabilization goal of reducing the balance-of-payments disequilibrium, while simultaneously liberalising trade-mainly through elimination of quantitative restrictions and reduction and harmonization of tariff rates. The latter measures would invariably lead to a significant rise in imports that would make it more difficult to restore balance-of-payment equilibrium. Here again, the successful implementation of somewhat conflicting measures called for a strong state.

In this decade, characterized by pro-market and anti-government rhetoric, there was strong sentiment to do away with aid altogether and have private capital flows substitute for it. Thus, in the early 1980s, the Reagan administration created a fertile environment for conservative critics of foreign aid who felt that 'economic assistance distorts the free operation of the market and impedes private sector development' (Ruttan 1996: 143). Clearly, the debt overhang put a damper on going too far in eliminating aid. Both public and private creditors in the industrialized world had too much at stake.

\section{The development doctrine in the 1990s}

In the first half of the 1990s, stabilization and adjustment were still the dominant objectives (see Figure 6). While most of the Latin American countries (and the few Asian countries affected by the debt crisis) had gone through a painful adjustment process and were back on a growth path, the overall situation was still one of stagnation-largely caused by poor governance in sub-Saharan Africa and most transition economies in Eastern Europe. It was becoming increasingly clear to the development community that fundamental and deep-rooted institutional changes to reduce corruption and facilitate a successful transition from socialism and command economies to market economies were a precondition to successful adjustment and a resumption of development in Eastern Europe and sub-Saharan Africa. Potentially the institutions and policies at the root of the East Asian 'miracle' could provide the model to follow. 
Figure 6: Development doctrine during the 1990s

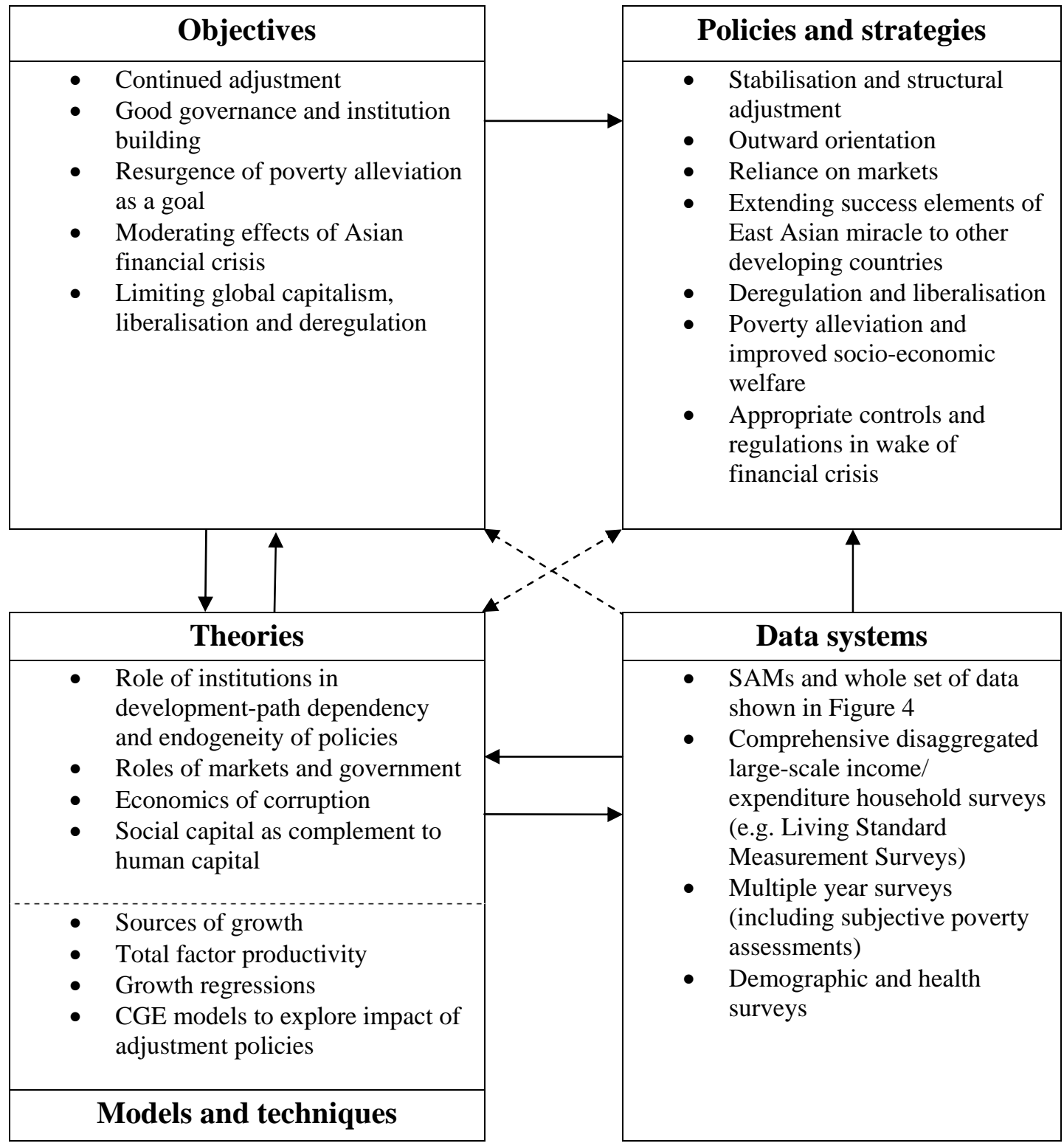

In the second half of the 1990s the Asian financial crisis hit East and Southeast Asia with a vengeance, resulting in a sharp reversal of the long-term poverty reduction trend. Simultaneously socioeconomic conditions deteriorated so drastically in the former Soviet republics that poverty alleviation in its broadest sense-including improvements in health, nutrition, education, access to information and to public goods and a participation in decision-making — resurfaced as the major, if not overarching, objective of development.

Another consequence of the financial crisis was to bring into question the Washington and IMF consensus of unbridled capital and trade liberalization and complete deregulation of the financial system. A number of East and Southeast Asian countries are still suffering from the extreme deregulation of the banking sector and capital flows that weakened the supervisory and monitoring functions of central banks and other 
institutions. The international monetary and financial system that still relies on the outdated Bretton Woods rules-of-the-game needs major revamping and a new set of rules befitting the contemporaneous environment. In the meantime, a number of affected countries were restoring controls on an ad hoc basis.

The conceptual contribution to development theory in the 1990s, in general, extended and further elaborated on earlier concepts. Perhaps the most fundamental issue that was debated during the 1990s is the appropriate roles of the state and the market, respectively, in development. An inherently related issue is to identify the set of institutions most conducive to the acceleration of the process of economic growth and socioeconomic development. Prior to the onset of the Asian financial crisis it was felt that the mix of institutions and policies adopted by the East Asian countries that gave rise to the East Asian miracle (World Bank 1993) provided a broad model, with parts of it potentially transferable to other developing countries. The financial crisis led to a more sceptical appraisal — even whether the miracle, after all, was not a 'myth'. In any case, the reliance on government actions in the previous decades to promote industrial growth on the part of East Asian countries (particularly South Korea) appeared suspect and came under heavy criticism. Some critics argued that the already impressive growth performance would have been even better with less government intervention-and that even if those industrial policies had contributed to growth they required a strong state, an element sorely missing in other parts of the Third World.

While the debate on the proper mix between the degree of government intervention and reliance on markets is still very much alive, the neo-institutional and public choice schools have helped clarify how the state can affect development outcomes. This can be done in a number of ways: (i) by providing a macroeconomic and microeconomic incentive environment conducive to efficient economic activity; (ii) by providing the institutional infrastructure-property rights, peace, law and order and rules - that encourages long-term investment, and (iii) by insuring the delivery of basic education, health care and infrastructure required for economic activity (Commander et al. 1996). Institutional capability as evaluated from the standpoint of entrepreneurs depends, in turn, on such indicators as predictability of rule-making, perception of political stability, crime against persons and property, reliability of judicial enforcement and freedom from corruption (Brunetti et al. 1997; Chibber 1998).

The role of institutions as a precondition to following a successful development path becomes even more critical if one subscribes to the new approach to political economy that takes institutions as largely given exogenously and argues that policies tend to be determined endogenously within a specific institutional context (Persson and Tabellini 1990). Thus, for example, if the central bank and the finance ministry are not independent or are operating under loose discretionary rules, the monetary and fiscal policies that result will depend on political and social factors (or according to the political power of the different lobbies in society and the public choice formulation). 
Two additional contributions worth highlighting in this decade are the concept of social capital and a better understanding of sources of growth (total factor productivity) and the need to explain the residual. Social capital was devised as a concept to complement human capital. If individuals are socially excluded, or marginalized, or systematically discriminated against, they cannot rely on the support of networks from which they are sealed off. Alternatively, membership of group organizations brings about benefits that can take a variety of forms (the provision of informal credit and help in the search for employment, for example). The acquisition of social capital by poor households is particularly important as a means to help them escape the poverty trap.

The spectacular growth of East Asian countries prior to 1997 renewed the interest in identifying, explaining and measuring the sources of growth. Recent studies tended to demystify the East Asian miracle by suggesting that the rapid growth of these economies depended on resource accumulation with little improvement in efficiency and that such growth was not likely to be sustainable (Krugman 1994; Kim and Lau 1994; Young 1995). This conclusion was based on estimates of total factor productivity (TFP) growth and depends crucially on the form of the production function used and on an accurate measurement of the capital and labour inputs. Whatever residual is left over is ascribed to technological progress. Some critics argue that typical TFP calculations significantly underestimate organizational improvements within firms or what Leibenstein called X-efficiency.

The 1990s witnessed an increased interest in CGE models used to simulate the impact of exogenous shocks and changes in policies on the socioeconomic system and particularly income distribution. A key issue explored in those models was that of the impact of adjustment policies on income distribution and poverty. General equilibrium models provide the only technique to compare the impact of alternative (counterfactual) policy scenarios, such as a comparison of the effects of an adjustment programme versus a counterfactual non-adjustment programme (Thorbecke 1991 for Indonesia; Sahn et al. 1996 for Africa).

This decade was marked by a proliferation of statistical information relating particularly to the socioeconomic characteristics and welfare of households-in addition to the more conventional data sources previously collected (see data box in Figure 6). A large number of quantitative poverty assessments based on household expenditure surveys were completed, as well as more qualitative participatory poverty assessments. Furthermore the availability of demographic and health surveys for many developing countries provided micro-level information on health and nutritional status, assets and access to public goods and services to supplement information on household consumption. Also, perhaps for the first time, the availability of multiple-year surveys and panel data for many countries allowed reliable standard of living and welfare comparisons to be made over time. 
In many respects, the development strategy of the 1990s was built upon the foundations of the preceding decade and retained most of the latter's strategic elements-at least in the first half of the decade. However, as the decade evolved, the adjustment-based strategy of the 1980s came under critical scrutiny that led to major changesparticularly in the wake of the Asian financial crisis. In sub-Saharan Africa, the great majority of the countries were still facing serious adjustment problems. A widely debated issue was whether adjustment policies per se without complementary reformswithin the context of Africa-could provide the necessary initial conditions for a take off into sustained growth and poverty alleviation. Two conflicting approaches to adjustment and diagnoses of its impact on performance were put forward. The 'orthodox' view, best articulated by the World Bank (at the beginning of the decade but subsequently modified), argued that an appropriate stabilization and adjustment package pays off. Countries that went further in implementing that package experienced a turnaround in their growth rate and other performance indicators.

In contrast, the 'heterodox' approach-best articulated by the concept of 'adjustment with a human face', embraced by UNICEF (see Cornia et al. 1987)—while supporting the need for adjustment, argued that the orthodox reforms focus extensively on shortterm stabilization and do not address effectively the deep-rooted structural weaknesses of African economies that are the main causes of macro instability and economic stagnation. Accordingly, major structural changes and institutional changes are needed to complement adjustment policies to induce the structural transformation (such as industrialization, diversification of the export base, the build-up of human capital and even land reform) without which sustainable long-term growth in Africa (and by extension in other developing countries facing similar initial conditions) is not possible.

The UNICEF and heterodox critical evaluation of the impact of adjustment policies on long-term growth and poverty alleviation - even when it was not appropriately justified on empirical grounds - sensitised multilateral and bilateral donors to the need to focus significantly more on the social dimensions of adjustment. It made a strong case for the implementation of a whole series of complementary and reinforcing reforms, ranging from greater emphasis on and investment in human capital and physical infrastructure to major institutional changes_-particularly in agriculture and industry-benefiting small producers. In turn, the orthodox approach has made a convincing case that appropriately implemented adjustment policies are not only a necessary condition to the restoration of macroeconomic equilibrium but can also contribute marginally to economic growth and poverty alleviation, in the short run.

In 1993, the World Bank published a very influential report on the East Asian miracle (World Bank 1993). The report analysed the success elements of the high performing Asian economies and argued that many of them were potentially transferable to other developing countries. In brief, these success elements consisted of: 
(i) sound macroeconomic foundations and stable institutions aiming at a balanced budget and competitive exchange rates;

(ii) technocratic regimes and political stability that provided policy credibility and reduced uncertainty—an important factor for foreign investors;

(iii) an outward (export) orientation;

(iv) reliance on markets;

(v) a more controversial set of industrial policies with selective government interventions often using 'contests' among firms as proxy to competition;

(vi) high rates of investment in building human capital;

(vii) high physical investment rates;

(viii) a process of technology acquisition consistent with dynamic comparative advantage; and

(ix) a smooth demographic transition. In particular, the outward orientation, encouraging exports was applauded as a means of acquiring state of the art technology which in turn would trigger a 'learning-by-doing' and 'learning-bylooking' (reverse engineering) process that would lead to spillover effects on human capital and positive externalities among firms within an industry and among industries.

The East Asian miracle also provided a convincing example of the essential importance of sound institutions (such as the balanced budget presidential decree in effect in Indonesia between 1967 and 1997) as preconditions to a sustainable process of growth with equity. The absence of institutions appropriate to a smooth transition from command to market economies in much of Eastern Europe and the fragility of existing institutions in much of sub-Saharan Africa provide painful counter examples of the enormous human costs of a weak institutional framework.

The Asian financial crisis that wrought havoc in much of East and Southeast Asia in 1997, forced a critical re-examination of an international trade and financial system based on excessive trade and capital liberalization and financial deregulation. The large increase in the incidence of poverty that followed in the wake of the crisis sensitised the development community to again focus on poverty alleviation and improvements in the socioeconomic welfare of vulnerable households as the overarching objective of development. Thus, at the end of the decade, the World Bank made it clear that poverty reduction -in its broadest sense-measured in terms of outcomes (health, education, employment, access to public goods and services and social capital) rather than inputs was the primary goal to strive for.

The crisis also triggered a re-examination of the role of government in protecting the economy from major shocks originating abroad. In particular, it pointed towards 
strengthening financial institutions and the provision of the minimum set of rules and regulations (for example, improved monitoring and supervision of the banking sector) to reduce corruption and speculative borrowing from abroad; and the establishment of institutional safety nets that could act as built-in-stabilisers following a crisis.

The decade of the 1990s was marked by a strong and lingering case of 'aid fatigue' evidenced by the absolute decline in net disbursements of official development assistance (ODA) after 1992. This downward trend reflected the strong faith in the operation of markets and scepticism regarding governments' (both aid donors and recipients) involvement in productive sectors such as agriculture and industry. Fatigue was also influenced by the rising fear that foreign aid was generating aid dependency relationships in poor countries and, as such, would have the same type of negative incentive effects that welfare payments have on needy households whose recipients might be discouraged from job searching.

A related issue that was critically debated in the 1990s was that of the effectiveness of aid conditionality. First of all, given fungibility, is it really possible to use aid to 'buy' good policies, or even a sound programme of public (current and capital) expenditures from aid recipients? From the standpoint of the political economy of external aid, structural adjustment can be looked at as a bargaining process between bilateral and multilateral donors, on the one hand, and debtor governments, on the other. Both sides may have a vested interest in following soft rules in their lending and borrowing behaviour, respectively. This tends to foster and continue a dependency relationship that may well be fundamentally inconsistent with a viable long-term development strategy for the recipient countries (particularly in sub-Saharan Africa).

The conditionality debate fuelled a number of econometric studies of aid's effectiveness based on international cross-sectional data. Perhaps the most influential one was that of Burnside and Dollar (2000) which concluded that aid can be a powerful tool for promoting growth and reducing poverty but only if it is granted to countries that are already helping themselves by following growth-enhancing policies. In contrast, Guillaumont and Chavet (2001) find that aid effectiveness depends on exogenous (mostly external) environmental factors such as the terms of trade trend, the extent of export instability and climatic shocks. Their results suggest that the worse the environment, the greater the need for aid and the higher its productivity. Hansen and Tarp (2001), using essentially the same cross-sectional dataset as do Burnside and Dollar, argue that when account is taken of unobserved country-specific fixed effects and the dynamic nature of the aid-growth relationship, the Burnside-Dollar conclusion fails to emerge. Country-specific characteristics of aid recipient countries-aside from the policy regime followed by those countries-have a major impact on aid's effectiveness. 
The socioeconomic havoc created by the Asian financial crisis engendered a fundamental re-examination of the role of aid and the uncritical acceptance of rules of the game, based on the outdated international trade and monetary system designed at Bretton Woods and the Washington Consensus no longer consistent with the contemporaneous conditions.

Reflective of the trend towards using aid as an instrument to fight poverty is the recent study by Collier and Dollar (1999) that develops criteria for allocating aid when the objective is to maximize poverty alleviation.

\section{Development doctrine in the present decade}

It has been claimed with some justification that the development community has run out of 'big ideas' at the beginning of this new millennium. Lindauer and Pritchett (2002), comparing the state of the art in 1962 and 1982 show the amazing reversal of big ideas between the two periods. In 1962 government played a central role and was the driving force behind development, while in 1982 the government was considered to be the main obstacle to development. Similar reversals are noted with respect to the accepted roles of accumulation, trade, foreign capital, and foreign aid, respectively, over these two decades. Fast forward to 2002, how would one advise, say, a president of a Latin American country? To quote Lindauer and Pritchett (2002: 2)

Any push toward deepening market reforms will be seen as a continuation of the failed strategies of the present, while any strategy that calls for government intervention and leadership ... will be seen as a reversion to the failed strategies of the past. What is of even deeper concern than the lack of an obvious dominant set of big ideas that command (near) universal acclaim is the scarcity of theory and evidencebased research on which to draw (emphasis added).

It can be argued that the last few years have been marked by a critical re-evaluation and consolidation of previous concepts and techniques as opposed to the formulation of brand new ideas per se. Figure 7 summarizes the main development characteristics of this decade. Arguably the most important contribution to development doctrine in this decade is a technique rather than a theory, for instance, the use of randomized and controlled experiments in the evaluation of development effectiveness (Duflo and Kremer 2003). As they argue, 'Any impact evaluation attempts to answer an essentially counterfactual question: how would individuals who participated in the programme have fared in the absence of the program?' Perhaps the best example of impact analysis is the quasi-experimental design used in evaluating the redistributive PROGRESA programme in Mexico that relied on the selection of target villages (receiving benefits) and control villages (not presently receiving benefits but eligible for benefits in future rounds). Programme effects are estimated by comparing treated individuals or 
Figure 7: Development doctrine during present decade (2000-2005)

\begin{tabular}{|c|c|}
\hline Objectives & Policies and strategies \\
\hline $\begin{array}{ll} & \text { Same objectives as in Figure } 6 \\
& \text { except revising and questioning } \\
& \text { the Washington Consensus } \\
\text { - } & \text { Human development } \\
\text { (e.g. education and health) } \\
\text { - } & \text { Poverty and inequality reduction } \\
\text { - } & \text { Millennium Development Goals } \\
\text { - } & \text { Reduce vulnerability }\end{array}$ & $\begin{array}{ll}\text { - } & \text { Globalization as development } \\
\text { strategy } \\
\text { - } & \text { Search for pro-poor growth } \\
& \text { development strategy }\end{array}$ \\
\hline Theories & Data systems \\
\hline $\begin{array}{ll}\text { - } & \text { Political economy of development } \\
& \text { and role of institutions } \\
\text { - } & \text { Growth-inequality-poverty nexus } \\
\text { - } & \text { Multi-dimensional poverty } \\
\text { - } & \text { Multiple equilibria }\end{array}$ & $\begin{array}{ll}\text { - } & \text { Same as in Figure } 6 \\
\text { - } & \text { More micro and panel data } \\
\text { - } & \text { sources } \\
\text { Data banks }\end{array}$ \\
\hline $\begin{array}{l}\text { Control and randomization } \\
\text { experiments } \\
\text { - Critique of growth regressions }\end{array}$ & \\
\hline Models and techniques & \\
\hline
\end{tabular}

communities to control individuals or communities. There is no question that this new methodology has revolutionized the evaluation of social programmes in such areas as education and health by providing a scientific base for the recommendations comparable to the design of drug and medical trials. On the other hand the limitation of this approach is that it only provides a precise and robust answer to a very narrow question, 'what is the effect of a specific programme within a specific context?'.

Researchers today appear consumed, if not overwhelmed, by what can be called the endogeneity curse or dragon. The emphasis is on combating the econometric biases and problems often to the exclusion of the importance of larger structural and conceptual issues. Controlled experiments have not enlightened us on the underlying mechanisms generating the outcomes. As Mookherjee (2004) points out 'The purpose is not to understand the underlying structure of the system of relationships generating the outcomes, only the statistical outcome impact of certain policy treatments'. Relying on reduced form relations without explicitly identifying and presenting the structural (and behavioural) model yielding the reduced form allows the researchers to by-pass what some would consider a fundamental prior step, namely, the theoretical foundation of the tested hypotheses. Another limitation of impact analysis is that it ignores entirely the general equilibrium effects of an intervention. Given those qualifications, this new methodology has generated a large number of excellent empirical studies of the impact of educational, health and other social interventions in a variety of different settings in 
poor countries. A recent survey (Glewwe 2002) concludes that this new methodology in the field of education provides an opportunity to make significant progress in understanding what to do in specific situations.

Randomized and controlled experiments appear to have largely replaced structural and behavioural models in the toolkit of development economists. The latter rely heavily on imposed assumptions regarding individual behaviour and rationality and even when econometric results suggest that the imposed structure can not be rejected, there is no guarantee that a better and still more general model might not exist and reflect observed behaviour more accurately. At the same time the potential strength of those models is that they capture explicitly the underlying structure and behaviour of the agents. It seems that a blending of those two approaches might be quite fruitful as long as it could be done in a fair way consistent with the existing norms and political economy setting. Combining programmes that use some randomization in selecting eligible recipients while also gathering sample survey data on both target and control groups to build structural models could relax somewhat the non-transferability of purely randomized experiments to other settings. Greater use of theory could help explain and clarify the (causal) mechanisms underlying findings generated by controlled experiments and permit a wider range of policy assessments (Mookherjee 2004).

Growth regressions, an important and popular tool of development economists ever since the days of Hollis Chenery, have recently come under heavy criticism. In fact, in an 'obituary for growth regressions', Lindauer and Pritchett (2002) provide many convincing technical reasons for rejecting growth regressions. Their basic flaw is that 'they confuse partial correlations with (stable) parameters and confuse empirical variables (that might be associated with policies) with feasible actions to promote growth'. The right hand side variables appearing in the reduced form equations-in the absence of an underlying structural and behavioural model actually yielding the reduced form - can be selected on spurious grounds simply because they are correlated with growth. Without an explicit model reflecting the underlying assumed theoretical mechanisms affecting the dependent variable (growth), some critics have dismissed those reduced form regressions as 'right hand side fundamentalism'. The popularity of this approach reflects again a relative lack of theoretical models capable of explaining convincingly the contemporaneous growth process.

On the positive side some important conceptual contributions are flourishing today. The first one can be categorized under the broad theme of the political economy of development and the role of institutions. One of its major tenets is that a more equal initial income and wealth distribution is consistent with and conducive to growth. The new political economy theories linking greater inequality to reduced growth operate through the following channels:

1) unproductive rent seeking activities that reduce the security of property; 
2) the diffusion of political and social instability leading to greater uncertainty and lower investment;

3) redistributive policies encouraged by income inequality that impose disincentives on the rich to invest and accumulate resources;

4) imperfect credit markets resulting in under-investment by the poor, particularly in human capital; and

5) a relatively small income share accruing to the middle class-implying greater inequality - has a strong positive effect on fertility which, in turn, has a significant and negative impact on growth.

This new approach turns on its head the prevailing view under the classical framework that an unequal income distribution is a pre-requisite to growth, based on the argument that the rich (the capitalists) save a larger proportion of their income than the poor (the workers). Hence, for a given level of total income a more unequal income distribution would generate a larger flow of aggregate savings that could be channelled into investment to yield a higher growth rate of GDP. In this sense the desirability of an unequal income distribution could be rationalized on economic grounds while clashing with the ethical concern for more equality, equity and egalitarianism. More poverty today was a pre-condition to more economic growth and less poverty in the future. As the Cambridge School baldly put it, impoverishment of the masses is necessary for the accumulation of a surplus over present consumption. If indeed equality is conducive to growth than it becomes a means towards economic development and future poverty alleviation and the conflict between the ethical objective (norm) of egalitarianism and the economic conditions required for growth disappears (Thorbecke 2006).

The new political economy of development approach relies extensively on the role of institutions. In an extremely influential article Acemoglu et al. (2001) made a strong case that development depends on institutional quality. They selected an instrumental variable, colonial settler mortality, that affects institutions exogenously but not income directly and were able to explain inter-country differences in per capita income as a function of predicted quality of institutions. Their hypothesis is that mortality rates among early European settlers in a given colony determined whether they would decide to establish resource-extractive or plundering institutions or to settle and build European institutions and, in particular, those protecting property rights. However, as Bardhan (2005) has argued, there are other types of institutions that matter for development such as participatory and accountability institutions and institutions that facilitate investment co-ordination.

A second and related contribution is to understand and explain the growth-inequalitypoverty nexus as an essentially indivisible process. Growth is a necessary (but not sufficient) condition for development to occur. If the initial income and wealth distribution is uneven then growth may not only be lower (as proponents of the new 
political economy of development would argue) but the impact of a given aggregate (GDP) growth rate on poverty-reduction will also be significantly smaller (the elasticity of poverty reduction with respect to growth varies within a wide range, between -0.2 and 3.0 depending on the initial conditions). Inequality can be thought of as the filter between growth and poverty.

In addition to the initial income distribution, the pattern and structure of growth play a fundamental role in their impact on poverty. Given the initial conditions, including the institutional framework in place at the time, the outcomes of the nexus of growth, inequality and poverty are jointly determined. This is essentially the theme of the World Development Report for 2006 (World Bank 2005) which argues convincingly that there need not be any tradeoff between growth (efficiency) and poverty reduction (equity). The key issue is to identify institutions and policies that are conducive to a pro-poor growth pattern.

A third recent contribution, also inter-related with the above two themes, is a much more comprehensive and multi-dimensional definition of human welfare than prevailed previously. Building on the foundations of Sen's functioning and capabilities concepts, human development, as opposed to the narrower concept of poverty-reduction, has taken over centre stage as the ultimate goal of development. Human development consists of a plethora of dimensions and aspects as they relate to health, education, nutrition, shelter, access to information, participation, nature of regime (degree of democracy and liberty) and many others. Conceptually, one can think of a human development profile over $n$ dimensions. An individual profile would consist of the specific values or scores of that individual on each of the indicators proxying the $n$ dimensions. Likewise, one could compute average regional and national profiles. Instead of deriving a scalar value by weighing each of the dimensions (as the UNDP Human Development Index does), complete profiles would be compared.

In some, probably unusual circumstances, one profile could reveal higher (better) values on each of the indicators of the $n$ dimensions. In this case the equivalent of first order stochastic dominance would obtain and it could be stated unambiguously that the level of human welfare was higher in the dominant profile. When one profile scores higher on some dimensions but lower on others, no unambiguous ranking can be established without linking each dimension of human welfare to some utility function. It is very difficult if not impossible to imagine that this mapping from dimension to utility can be done totally objectively in a non-arbitrary fashion. In this case, as two profiles intersect, one can check whether second or higher order (stochastic) dominance obtains. Until now the theoretical and empirical work on multi-dimensional welfare has been focused on and limited to the measurement of multi-dimensional poverty as opposed to the even broader concept of human development (Bourguignon and Chakravarty 2003; Tsui 2002; Duclos et al. 2006). In many respects, this approach goes back to, and represents a much more sophisticated version of the Basic Needs doctrine of the 1970s. A 
complementary approach also meant to broaden the concept and measurement of poverty is the attempt at blending objective and quantitative (essentially money-metric) indicators and more subjective and qualitative indicators (à la Sussex School) based on focus groups and interviews (Kanbur 2004).

A final theoretical construct that is presently in vogue and that appears promising in exploring a variety of issues in development economics is that of multiple equilibria. Ray (2000) provides a vivid example drawn from Rosenstein-Rodan's (1943) Big Push notion and Hirschman's (1958) backward and forward linkages concept. These pioneers argued that economic development could be thought of as a massive co-ordination failure, in which several investments do not occur simply because of the absence of other complementary investments and similarly, these latter investments are not forthcoming because the former are missing. To quote Ray (2000: 5):

Thus one might conceive of two equilibria under the very same fundamental conditions, one in which active investment is taking place, with each industry's efforts motivated and justified by the expansion of other industries, and another equilibrium involving persistent stagnation, in which the inactivity of one industry seeps into another. This serves as an explanation of why similar economies may behave very differently

Institutions and policies might be viewed as tools for moving an economy out of one (bad) equilibrium into another (good) one. In a dynamic sense this process corresponds to a phase transition. If economic development is conceived as one of phase transitions, it carries far-reaching implications for the role of government. Institutions have to be established and policies designed and implemented that facilitate the phase transition. One implication is that the emphasis on temporary, one-time interventions is likely to be much greater and if successful will not have to be repeated. If and once the new (good) equilibrium is reached it is presumably sustainable within the new institutional and policy framework. It would be like jump-starting a car whose battery had run down.

The objectives and definition of development have been further broadened in this decade. As discussed above, improvement in human development is increasingly seen as the ultimate goal to strive for. Since a case has been made that less inequality in the income and wealth distribution can be conducive to growth and future development, greater equality has taken its place along poverty reduction as joint objectives to be reached through a pattern of growth sensitive to the needs of the poor. The Millennium Development Goals provide a general framework to monitor the progress of the Third World in its search for improving its level of human welfare. Although it is too early to predict confidently, it appears that most of the Millennium Goals have been set at an unrealistically high level and are therefore very unlikely to be attained. There is one more objective that has surfaced recently, namely reduced vulnerability. Since the poor in an era of globalization tend to be more vulnerable to external (essentially macroeconomic shocks) as the Asian Financial Crisis of 1997 demonstrated, it is 
important to design and implement a set of safety nets and structural measures that would reduce their vulnerability.

The datasets available to the development community are essentially the same as in the previous decade except for the availability of more panel data information useful in tracing the dynamics of poverty and many new cross-country databases on inequality and many other micro and macro variables. Increasingly, data banks are being created by different institutions that can be easily accessed by researchers worldwide.

The formulation of development strategy in this decade has to be scrutinized within the context of a world economy that is globalizing at a very fast rate. A key issue is whether the present form of globalization/integration is conducive to a process of growth-cumstructural transformation, which is capable of engendering and sustaining pro-poor economic growth and favourable distributional consequences. It is possible, contrary to the income convergence thesis, that globalization could generate, both at the national and global levels, adverse distributional consequences that could slow down the present poverty alleviation trend (Nissanke and Thorbecke 2006).

Hence, policymakers need to design and implement an active development strategy not only to benefit from, but also to help counteract some of the negative effects of the immutable forces of globalization. Globalization should not be viewed as a reliable substitute for a domestic development strategy. It is not enough for governments to assume an active role in liberalizing trade and capital movements and deregulating their economies, while passively waiting for the fruits of the Washington Consensus and the market forces of globalization to pull them on a fast development track. Instead, governments need to pursue both active liberalization and active domestic development policies.

Globalization offers large potential benefits for those countries that decide to engage strategically and actively in the globalization process. Benefits are neither automatic nor guaranteed. Passive liberalization may lead to marginalization. At the same time those countries that are still stagnating (most of sub-Saharan Africa) need to strengthen institutions as well as to invest in agriculture in order to reach the takeoff point for structural transformation of their economies to proceed.

\section{Conclusions}

The retrospective appraisal revealed the close interdependence and evolution among development objectives, the conceptual framework and models, data and information systems, and development strategies throughout the last six decades. In each period the nature and scope of the prevailing development strategy was influenced, and sometimes predetermined, by the conceptual state of the art and the available data systems. The interdependent evolution among the four elements of the development doctrine can 
perhaps best be brought to light by the gradual progression which these elements underwent through time. The definition of development broadened from being tantamount to GNP growth, as both an objective and a performance criterion, to growth and employment, to the satisfaction of basic needs and, ultimately, to the enhancement of human welfare and the reduction of multi-dimensional poverty to be achieved through a pattern of pro-poor growth. Thus, development evolved from an essentially scalar concept to a multi-dimensional one entailing the simultaneous achievement of multiple objectives.

A parallel progression occurred in development theory. During the 1950s the analytical framework was completely aggregative and relied on one-sector models. In the 1960s the prevailing framework became dualistic, distinguishing between an urban, modernindustrial sector and a rural, traditional-agricultural sector. Gradually as distributional issues became paramount major breakthroughs in the analysis and measurement of poverty occurred. A concern for structural issues early on gave way to a concern with the role of institutions and the market in the development process. The somewhat idealized and misplaced faith in planning which characterized the early decades was replaced by an arguably controversial over-reliance in the effectiveness of markets as an engine of development and as a corollary the minimization of the role of governments. Endogenous growth requires governments capable of intervening in areas such as education and health to yield the spillover effects of investment in human capital on overall development. In the present era of globalization the appropriate roles of governments and markets is one of the most debated issues.

The advance in the coverage and quality of the data and data systems needed for development analysis and policy over the last half century as been remarkable. Until the 1970s the statistical information available to researchers and government offices consisted almost exclusively of national accounts, population, agricultural and manufacturing censuses and, in a few instances, simple input-output tables. Survey type information on variables such as employment, income, consumption and savings patters tended to be scarce and not very representative. Thus, in general, the existing data systems were not conducive to empirical studies which could illuminate such fundamental issues as the state of income distribution and the incidence of poverty. From the 1980s on, the coverage of household survey data expanded enormously and allowed a plethora of microeconomic studies to be conducted on a large variety of issues related to human welfare such as health and education. In turn, the evolution in the quality and comprehensiveness of Social Accounting Matrices worldwide provided a necessary bridge between the macro and the microeconomic settings. Computable general equilibrium models and macro-micro simulation models made it possible, within limits, to estimate the impact of macroeconomic policies and shocks on the earnings and incomes of different socioeconomic household groups and even, in some instances, on individual households. The parallel progress in theoretical concepts and in 
data systems opened up the domain of distributional issues to more rigorous investigation.

Notwithstanding a possible shortage of 'big ideas' in the present decade, we can agree with Bardhan's (1993: 139-40) conclusion, in his assessment of the state of development economics that

While the problems of the world's poor remain as overwhelming as ever, studying them has generated enough analytical ideas and thrown up enough challenges to the dominant paradigm to make all of us in the profession somewhat wiser, and at least somewhat more conscious of the possibilities and limitations of our existing methods of analysis.

\section{References}

Acemoglu, D., J.A. Robinson, and S. Johnson (2001). 'The Colonial Origins of Comparative Development', American Economic Review 91(5): 1369-2002.

Bardhan, P.K. (1989). The Economic Theory of Agrarian Institutions, Clarendon Press: Oxford.

Bardhan, P.K. (1993). 'Economics of Development and the Development of Economics', Journal of Economic Perspectives 7(2): 129-42.

Bardhan, P.K. (2005). 'Theory of Empirics in Development Economics', Economic and Political Weekly, 1 October.

Bourguignon, F., and S.R. Chakravarty (2003). 'The Measurement of Multidimensional Poverty', Journal of Economic Inequality 1: 25-49.

Brunetti, A., G. Kisunko, and B. Weder (1997). Economic Growth with 'Incredible' Rules: Evidence from a Worldwide Private Sector Survey', background paper for World Development Report 1997, World Bank: Washington DC.

Burnside, C., and D. Dollar (2000). 'Aid, Policies, and Growth', American Economic Review 90(4): 847-68.

Chenery, H.B. (1953). 'Application of Investment Criteria', Quarterly Journal of Economics 67: 76-96.

Chenery, H.B. (1960). 'Patterns of Industrial Growth', American Economic Review 50 (4): 624-54.

Chenery, H.B., and A.M. Strout (1966). 'Foreign Assistance and Economic Development', American Economic Review 56(4): 679-733.

Chenery, H.B., and L. Taylor (1968). 'Development Patterns: Among Countries and Over Time', Review of Economics and Statistics 50(4): 391-416.

Chenery, H.B., M.S. Ahluwalia, C.L.G. Bell, J.H. Duloy, and R. Jolly (eds) (1974). Redistribution with Growth, Oxford University Press: New York.

Chibber, A. (1998). 'Institutions, Policies and Development Outcomes', in R. Picciotto and E. Wiesner (eds) Evaluation and Development: The Institutional Dimension, Transaction Publishers: New Brunswick and London. 
Collier, P., and D. Dollar (1999). 'Aid Allocation and Poverty Reduction', Policy Research Working Papers 2041, Development Research Group, World Bank: Washington DC.

Commander, S., H. Davoodi, and U.J. Lee (1996). 'The Causes and Consequences of Government for Growth and Wellbeing', background paper for World Development Report 1997, World Bank: Washington DC.

Cornia, G., R. Jolly, and F. Stewart (1987). Adjustment with a Human Face: Protecting the Vulnerable and Promoting Growth, Clarendon Press: Oxford.

de Janvry, A., E. Sadoulet, and E. Thorbecke (1993).'Introduction to State, Market, and Civil Organizations: New Theories, New Practices, and Their Implications for Rural Development', World Development 21(4): 565-75.

Dervis, K., J. de Melo, and S. Robinson (1982). General Equilibrium Models for Developing Countries, Cambridge University Press: London.

Duclos, J.-Y., D. Sahn, and S. Younger (2006). 'Robust Multidimensional Poverty Comparisons', Economic Journal 116(514): 943-68.

Duflo, E., and M. Kramer (2003). 'Use of Randomization in the Evaluation of Development Effectiveness', paper prepared for the World Bank Operations Evaluation Department Conference, World Bank: Washington DC.

Eckstein, A. (1957). 'Investment Criteria for Economic Development and the Theory of Intertemporal Welfare', Quarterly Journal of Economics 71(1): 56-85.

Fei, J.C.H., and G. Ranis (1964). Development of the Labor Surplus Economy, Irwin: Homewood IL.

Foster, J., J. Greer, and E. Thorbecke (1984). 'A Class of Decomposable Poverty Measures', Econometrica 52: 761-66

Fox, K., J.K. Sengupta, and E. Thorbecke (1972). The Theory of Quantitative Economic Policy, North Holland: Amsterdam.

Galenson, W., and H. Leibenstein (1955). 'Investment Criteria, Productivity and Economic Development', Quarterly Journal of Economics 69(3): 343-70.

Glewwe, P. (2002). 'Schools and Skills in Developing Countries: Education Policies and Socioeconomic Outcomes’, Journal of Economic Literature 40(2): 436-82.

Guillaumont, P., and L. Chavet (2001). 'Aid and Performance: A Reassessment', Journal of Development Studies 37(6): 66-92.

Hansen, H., and F. Tarp (2001). 'Aid and Growth Regressions', Journal of Development Economics 64: 547-70.

Harris, J., and M. Todaro (1970). 'Migration, Unemployment \& Development: A TwoSector Analysis’, American Economic Review 60(1):126-42.

Hirshman, A. (1958). The Strategy of Economic Development, Yale University Press: New Haven.

Hunt, D. (1989). Economic Theories of Development, Harvester Wheatsheaf: London.

ILO (1973). Employment, Income and Equality: A Strategy for Increasing Productive Employment in Kenya, International Labour Organization: Geneva.

Johnston, B.F., and P. Kilby (1975). Agriculture and Structural Transformation, Oxford University Press: London. 
Kahn, A.E. (1951). 'Investment Criteria in Development Programmes', Quarterly Journal of Economics 65: 38-61.

Kanbur, R. (ed.) (2004). Q-Squared: Qualitative and Quantitative Methods of Poverty Appraisal, Permanent Black: New Delhi.

Kim, J.I., and L.J. Lau (1994). 'The Sources of Economic Growth of East-Asian Newly Industrialized Countries', Journal of the Japanese and International Economies 8(3): 235-71.

Krugman, P.R. (1994). 'The Myth of Asia’s Miracle’, Foreign Affairs 73(6): 62-78.

Kuyvenhoven, A. (1978). Planning with a Semi-Input-Output Method, mimeo, Leiden.

Kuznets, S. (1966). Modern Economic Growth, Yale University Press: New Haven.

Leibenstein, H. (1957). Economic Backwardness and Economic Growth, Wiley: New York.

Lewis, W.A. (1954). 'Economic Development with Unlimited Supplies of Labour', The Manchester School of Economic and Social Studies 22(2): 139-91.

Lindauer, D.L., and L. Pritchett (2002). 'What's the Big Idea? The Third Generation of Policies for Economic Growth’, Economia 3(1): 1-39.

Little, I.M.D., and J. Mirrlees (1974). Project Appraisal and Planning for Developing Countries, Basic Books: New York.

Lucas, R.E. (1988). 'On the Mechanics of Economic Development', Journal of Monetary Economics 22(1): 3-42.

Manne, A.S. (1974). 'Multi-Sector Models for Development Planning, A Survey', Journal of Development Economics 1(1):43-69.

Mookherjee, D. (2004). 'Is There Too Little Theory in Development Economics Today?', Economic and Political Weekly 1 October.

Nabli, M.K., and J.B. Nugent (1989). 'The New Institutional Economics and Its Applicability to Development’, World Development 17(9): 1333-48.

Nissanke, M., and E. Thorbecke (2006). 'Channels and Policy Debate in the Globalization-Inequality-Poverty Nexus’, World Development 34(8): 1338-60.

North, D. (1990). Institutions, Institutional Change and Economic Performance, Cambridge University Press: Cambridge and New York.

Nurkse, R. (1953). Problems of Capital Formation in Underdeveloped Countries, Oxford University Press: New York.

Pant, P. (1974). 'Perspective of Development: 1961-1976. Implications for Planning for a Minimum Level of Living', in T.N. Srinivasan and P.K. Bardhan (eds) Poverty and Income Distribution in India, Calcutta Statistical Publishing Society: Calcutta.

Persson, T., and G. Tabellini (1999). Macroeconomic Policy, Credibility, and Politics, Hardwood Academic Publishers: New York and Melbourne.

Ray, D. (1998). Development Economics, Princeton University Press: Princeton.

Ray, D. (2000). 'What is New in Development Economics?', The American Economist 44: 3-16.

Romer, P. (1990). 'Endogenous Technological Change', Journal of Political Economy 98(5, part 2) S71-102. 
Rosenstein-Rodan, P.M. (1943). 'Problems of Industrialization of Eastern and SouthEastern Europe’, Economic Journal 53(210): 202-11.

Rostow, W.W. (1956). 'The Take-Off into Self-Sustained Growth', Economic Journal 66: 25-48.

Ruttan, V.W. (1996). United States Development Assistance Policy: The Domestic Politics of Foreign Economic Aid, Johns Hopkins University Press: Baltimore.

Sahn, D.E., P. Dorosh, and S. Younger (1996). 'Exchange Rate, Fiscal and Agricultural Policies in Africa: Does Adjustment Hurt the Poor?', World Development 24(4): 719-47.

Sen, A.K. (1985). Commodities and Capabilities, North Holland: Amsterdam.

Thorbecke, E. (ed.) (1969). The Role of Agriculture in Economic Development, Columbia University Press: New York.

Thorbecke, E. (1991). 'Adjustment, Growth and Income Distribution in Indonesia', World Development 19(11): 1595-614.

Thorbecke, E. (1993). 'Impact of State and Civil Institutions on the Operation of Rural Market and Non-Market Configurations', World Development 21(4): 591-605.

Thorbecke, E. (2000). 'The Evolution of the Development Doctrine and the Role of Foreign Aid, 1950-2000’, in F. Tarp (ed.) Foreign Aid and Development, Routledge: London.

Thorbecke, E. (2006). 'Economic Development, Equality, Income Distribution and Ethics', in M. Altmann (ed.) Handbook of Contemporary Behavioural Economics: Foundations and Developments, Sharpe: Armonk NY.

Tsui, K.Y. (2002). 'Multidimensional Poverty Indices', Social Choice and Welfare 19: 69-93.

Williamson, O. (1991). 'Comparative Economic Organization: The Analysis of Discreet Structural Alternatives’, Administrative Science Quarterly 36(2): 269-96.

Winters, L.A. (2004). 'Trade Liberalization and Economic Performance: An Overview', Economic Journal 114: F4-F21.

World Bank (1993). The East Asian Miracle, World Bank: Washington DC.

World Bank (2005). World Development Report; Equity and Development, World Bank: Washington DC.

Young, A. (1995). 'The Tyranny of Numbers: Confronting the Statistical Realities of the East-Asian Growth Experience', Quarterly Journal of Economics 110(3): 641-80. 